\title{
Projecting and valuing domestic water use at regional scale: A generic method applied to the Mediterranean at the 2060 horizon
}

\author{
Noémie Neverre ${ }^{\mathrm{a}, \mathrm{b}, \mathrm{d}, *}$, Patrice Dumas ${ }^{\mathrm{a}, \mathrm{c}}$ \\ ${ }^{a}$ Centre International de Recherche sur l'Environnement et le Développement (CIRED), Campus du Jardin Tropical, 45 bis avenue de la Belle Gabrielle, 94736 Nogent sur Marne, \\ France \\ ${ }^{\mathrm{b}}$ Centre National de la Recherche Scientifique (CNRS), 3 rue Michel-Ange, 75016 Paris, France \\ ' Centre de coopération Internationale en Recherche Agronomique pour le Développement (CIRAD), 42 rue Scheffer, 75016 Paris, France \\ d Ecole Nationale des Ponts et Chaussées (ENPC), Cité Descartes, 6-8 avenue Blaise Pascal, 77455 Champs-sur-Marne, France
}

\section{A R T I C L E I N F O}

Article history:

Received 24 October 2014

Received in revised form

29 May 2015

Accepted 11 June 2015

Keywords:

Domestic water demand

Water value

Projection

Hydroeconomic modelling

Mediterranean

\begin{abstract}
A B S T R A C T
The present work focuses on the demand side of future water scarcity assessment, and more precisely on domestic water demand. It proposes a quantitative projection of domestic water demand, combined with an original estimation of the economic benefit of water at large scale. The general method consists of building economic demand functions taking into account the impact of the level of equipment, proxied by economic development. The cost and the price of water are assumed to grow with economic development.

The methodology was applied to the Mediterranean region, at the 2060 horizon. Our results show the evolution of water demand and value, measured by surplus, over time. As long as GDP per capita and water price remain low, demand per capita increases along with economic development, and surplus per capita increases with demand. As demand approaches saturation, the combined negative effects of water cost and price increase on surplus grow stronger, and surplus per capita begins to decrease.

The developed methodology is meant to be used for large-scale hydroeconomic modelling, in particular for regions with heterogeneous levels of development and low data-availability.
\end{abstract}

(c) 2015 Elsevier B.V. All rights reserved.

\section{Introduction}

Pressure on water resources is a major issue in the Mediterranean region. More than half of the world's "water-poor" population is located in the region, which concentrates $7.3 \%$ of the world's population for only $3 \%$ of its water resources [23]. Global changes are expected to exacerbate this pressure on resources in the following decades: on the one hand water demand will increase with demographic growth and economic development, while on the other hand climate change is predicted to reduce water availability and intensify droughts around the Mediterranean [7].

Spatially contrasted situations, with some basins more affected by water scarcity than others, could foster water related interactions between basins such as water transfers, activity relocations

\footnotetext{
* Corresponding author at: Centre International de Recherche sur l'Environnement et le Développement (CIRED), Campus du Jardin Tropical, 45 bis avenue de la Belle Gabrielle, 94736 Nogent sur Marne, France.

E-mail addresses: neverre@centre-cired.fr (N. Neverre), dumas@centre-cired.fr (P. Dumas).
}

and, indirectly, migrations. Such interactions could particularly arise in the case of the Mediterranean, which has a history of exchanges and migrations between rims [9].

In such a context, it is important to anticipate future water scarcity issues and identify basins at risk, in order to inform management strategies and policies. Traditionally, water management policies focused on adapting supply to demand, by mobilizing new water resources. But as resources become increasingly scarce and costly, policy makers have developed demand side management aiming at reducing water wastage.

In the present work we concentrate on the demand side of the water scarcity issue, and more precisely on domestic water demand. Irrigation is the largest water use sector in the Mediterranean, representing $63 \%$ of total water use [23], and its projection is a research field of interest [10]. However, its share in total water use is decreasing [23]. Moreover, domestic demand, while accounting for a lower share of demand, is critical in terms of needs. Indeed, irrigation needs can be adjusted to some extent by virtual water trade, water scarce areas having the possibility of importing food rather than producing it themselves [4]. Domestic needs cannot be adjusted in that way. In addition, domestic uses such as 
consumption, food preparation and hygiene are essential to human life.

Some projections of domestic water use in Mediterranean countries exist, but they are not homogeneous between countries in terms of time horizons, methods and scenarios. In most cases they rely on simple trend prolongations [23]. When looking at the whole region, a global projection methodology applicable to the different countries, taking into account sociodemographic changes to come and simulating comparable scenarios across countries, is pertinent.

Generic global scale modelling of domestic water use is covered extensively in the literature $[2,3,17,34,35]$. The general principle is to model and project a unitary water use intensity per capita, that is to be multiplied by the projected number of inhabitants. In the WaterGAP methodology [1], the per capita water use intensity is modelled to evolve with the level of economic development (relationship statistically estimated at country scale) and decrease over time with technological improvement (represented by a fixed rate of improvement). In the Total Runoff Integrating Pathways (TRIP) model, future levels of domestic water use per capita in developing countries have been modelled either to converge towards that of present developed countries as economic growth continues [32,19], or independent of economic growth [17]. Other authors consider the impact of additional factors: Hughes et al. [21] statistically estimate municipal water use per capita as a function of climatic variables and GDP per capita; Ward et al. [35] estimate municipal water demand as a function of GDP per capita and urbanisation rate, taking into account regional dummies and country characteristics as fixed effects.

While evaluating water quantities at stake is essential, it is also relevant to have an idea of the economic benefits associated with water uses and the potential economic losses associated with water shortage. Economic valuation can be an indication on how to manage at best the available resource and allocate it between competitive uses when water is scarce. In hydroeconomic models, instead of considering water demands as fixed requirements, water is allocated to its different uses based on the economic benefits it generates: the economically optimal allocation is the one that maximises the aggregated economic value of the water used [18].

However, economic valuation of domestic water, as well as methods to project changes in water value, is absent from the large-scale literature. Because markets are absent or inefficient for the water sector, it is not possible to observe directly the economic value of water. It is necessary to develop alternative non-market valuation techniques to reveal and estimate water's value [37]. For the domestic sector, water is valued using willingness to pay and deriving economic surplus from econometric estimations of priceelasticity and demand functions [37]. Such a method requires much data, which could be among the reasons explaining why hydroeconomic models have been developed mainly at an infranational geographical scale [18].

To account for changes in both demands and economic benefits, in a region with heterogeneous data-availability, we develop an original generic method. We build an economic demand function, analogous to the demand function modelling approach used in hydroeconomic models of smaller scale [28], which enables water valuation. In order to take into account the link between water use and economic development, a methodology similar to WaterGap [1] is used.

This paper first describes the methodology developed to build generic demand functions that project both quantities and economic values of future domestic water demands at large scale and at a time horizon enabling to picture global changes (cf. diagram in Appendix A). Then it proposes an application to countries of the Mediterranean rim, from Western and Eastern Europe, Middle East and North Africa (cf. map of Mediterranean countries in Appendix B).

\section{Building generic demand functions taking into account structural change}

\subsection{Overview}

Our approach is to build simple three-part inverse demand functions (Fig. 1), in which the willingness to pay for water decreases with quantity [18]. Each part of the demand function corresponds to a different category of use. The first category corresponds to basic water requirements for consumption, food and hygiene, which are very highly valued (e.g. hand washing). The second category corresponds to intermediate needs, including additional hygiene (regular laundry, showers, etc.), less valued than uses of the first category. The last category corresponds to least-valued supplementary consumption, such as further indoor uses (e.g. leisure bath) or outdoor uses (lawn watering, pool, fountain, etc.).

To build a demand function for each country, we determine the bounds of the demand blocks corresponding to these three categories: their respective volume limits (noted $Q$ ) and the marginal willingness to pay (noted $V$ ) for those volumes.

Hence, the first step of the methodology is to determine the volume limits of the demand blocks, taking into account that demand will be impacted by economic development processes. The second step is to determine the willingness to pay for water at those volumes of reference, in order to value water. This second step also makes it possible to take into account the possible impact of water price on demand.

\subsection{Volumes of the demand blocks: taking into account structural change}

Following Alcamo et al. [1] and their "structural change" modelling, we want to take into account that average domestic water demand per capita grows along with economic development, proxied by GDP per capita, in order to take into account equipment effects. Indeed, as their income increases households get more water-using appliances (washing machines, dishwasher, etc.) and use more water; eventually they reach equipment saturation and water use stabilises whilst income continues to grow. To take into account structural change, we consider that the volumes of the blocks of our demand function evolve over time following economic development.

We assume that only non-essential uses are sensitive to this equipment effect, so we consider that the volume of the first block of our demand function is fixed. Following Gleick [16] and Howard and Bartram [20] (Table 1), we set the volume limit of the first demand block to $50 \mathrm{l} / \mathrm{c} / \mathrm{d}$, which meets needs for consumption, food and personal hygiene.

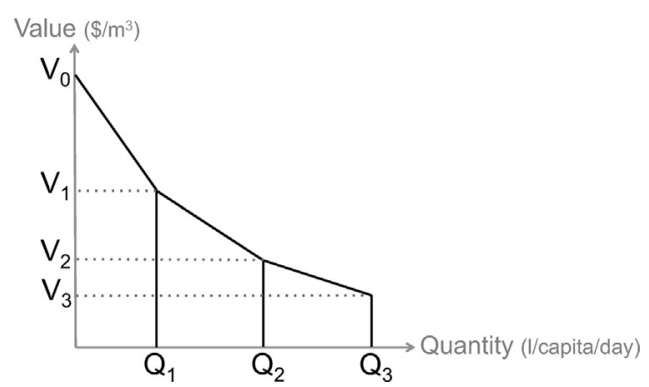

Fig. 1. General structure of the three-part inverse demand function (with volumes $Q$ and willingness to pay $V$ ). 
Table 1

Domestic water supply levels of reference, in litres per capita per day $(\mathrm{l} / \mathrm{c} / \mathrm{d})$. The figures $50 \mathrm{l} / \mathrm{c} / \mathrm{d}$ and $100 \mathrm{l} / \mathrm{c} / \mathrm{d}$ are used in the demand function.

\begin{tabular}{|c|c|c|}
\hline $\begin{array}{l}\text { Water sup- } \\
\text { ply (l/c/d) }\end{array}$ & Description & Author \\
\hline 100 & Fair level of domestic supply & $\begin{array}{l}\text { Falkenmark and } \\
\text { Lindh [12] }\end{array}$ \\
\hline 50 & $\begin{array}{l}\text { Recommended basic water requirements } \\
\text { Drinking water }: 5 \mathrm{l} / \mathrm{c} / \mathrm{d} \\
\text { Sanitation services : } 20 \mathrm{l} / \mathrm{c} / \mathrm{d} \\
\text { Bathing : } 15 \mathrm{l} / \mathrm{c} / \mathrm{d} \\
\text { Cooking and kitchen }: 10 \mathrm{l} / \mathrm{c} / \mathrm{d}\end{array}$ & Gleick [16] \\
\hline 20 & $\begin{array}{l}\text { Basic access: high level of health concern } \\
\text { Consumption : should be assured } \\
\text { Hygiene : hand-washing and basic food } \\
\text { hygiene possible; laundry and bathing } \\
\text { difficult to assure }\end{array}$ & $\begin{array}{l}\text { Howard and Bar- } \\
\text { tram }[20]\end{array}$ \\
\hline 50 & $\begin{array}{l}\text { Intermediate access: low level of health } \\
\text { concern } \\
\text { Consumption : assured } \\
\text { Hygiene : all basic personal and food hy- } \\
\text { giene assured; laundry and bathing } \\
\text { should also be assured }\end{array}$ & \\
\hline 100 & $\begin{array}{l}\text { Optimal access: very low level of health } \\
\text { concern } \\
\text { Consumption : all needs met } \\
\text { Hygiene : all needs should be met }\end{array}$ & \\
\hline
\end{tabular}

The volumes of the second and third demand blocks are assumed to evolve with the level of GDP per capita, with a saturation, drawing a sigmoid curve (Fig. 2). When GDP per capita is low, water demand is composed of only basic uses and intermediate uses (categories 1 and 2); intermediate uses grow with economic development. Then, as GDP per capita further increases, third category uses appear and the third demand block grows along with the intermediate demand block. Eventually, demand reaches saturation and stabilises.

To determine the total demand $\left(Q_{t o t}\right)$ structural change curve, we use the sigmoid function $f_{\text {tot }}$ :

$Q_{\text {tot }}=f_{\text {tot }}(G D P)=m_{\text {tot }}+M_{\text {tot }} \cdot\left[1-\exp \left(-\gamma_{t o t} \cdot G D P^{2}\right)\right]$

The function $f_{\text {tot }}$ is defined by three parameters: the minimum demand $\left(m_{t o t}\right)$, the maximum additional demand $\left(M_{t o t}\right)$ and the curve parameter $\left(\gamma_{t o t}\right)$; GDP stands for average GDP per capita. Parameter $m_{\text {tot }}$ is set to match basic needs: $m_{\text {tot }}=Q_{\text {basic }}=50 \mathrm{l} / \mathrm{c} / \mathrm{d}$. The two remaining parameters of $f_{\text {tot }}$ are to be statistically estimated at country scale using GDP, population and domestic water demand data (Section 3.1).

Then, to distinguish between second-block and third-block

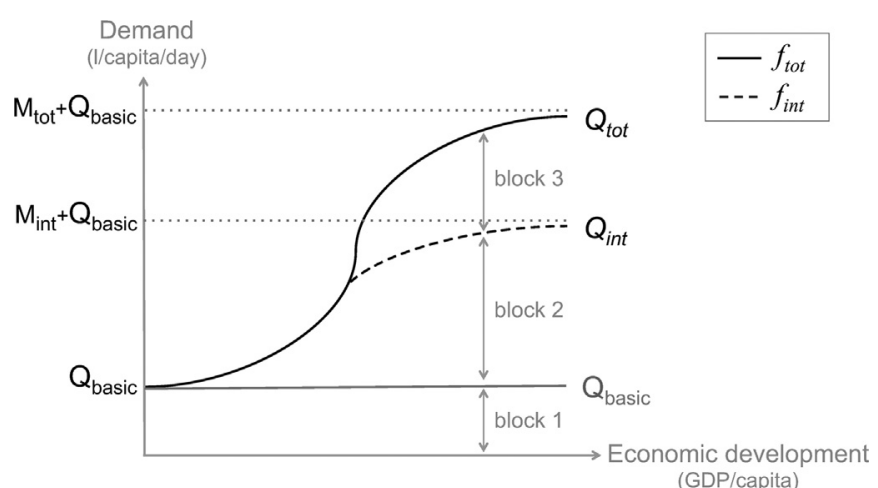

Fig. 2. Evolution of domestic water demand with economic development: "structural change" modelling (with volumes $Q_{b a s i c}, Q_{i n t}$ and $Q_{\text {tot }}$ ). volumes, we introduce the following sigmoid curve $f_{\text {int }}$ :

$f_{\text {int }}(G D P)=m_{\text {int }}+M_{\text {int }} \cdot\left[1-\exp \left(-\gamma_{\text {int }} \cdot G D P^{2}\right)\right]$

This curve $f_{\text {int }}$ is defined only starting from its intersection with $f_{\text {tot }}$, noted $\left(G D P^{\circ}, Q^{\circ}\right)$. Before this wealth level $G D P^{\circ}$, demand of the third category is null; after, intermediate demand is $Q_{\text {int }}=f_{\text {int }}(G D P)$, and demand of the third category is $Q_{\text {tot }}-Q_{\text {int }}$ (Fig. 2).

Parameters of $f_{\text {int }}$ are completely determined without need for a statistical estimation. First, we set $m_{\text {int }}=Q_{\text {basic }}=50 \mathrm{l} / \mathrm{c} / \mathrm{d}$. Then $M_{\text {int }}$ is set so as to match the reference figures of a "fair level of domestic supply" from the literature [12,20]: $M_{\text {int }}+m_{\text {int }}=100 \mathrm{l} / \mathrm{c} / \mathrm{d}$ (Table 1 ). Finally, we constrain $f_{\text {int }}$ by setting its inflection point so as to belong to the curve $f_{\text {tot }}$, which determines $\gamma_{\text {int }}$.

Once structural change curves parameters are calibrated for a chosen country, the volumes of the blocks of its demand function can be determined for a given year depending on the level of GDP per capita (Fig. 2).

\subsection{Willingness to pay for water along the demand function}

Once the volumes of water demand are determined, we estimate the willingness to pay (WTP) for water along the demand function. The following section describes how we determine the WTP at the lower and upper bound volumes of each category (i.e. 1 st, 50th and 100th $1 / \mathrm{c} / \mathrm{d}$, and maximum potential demand), then interpolate linearly.

We collected econometric studies, located in the Mediterranean region or in Europe, that estimate the response of domestic water demand to price. Studies that provided both estimated price elasticities and observed levels of price and demand were used to calculate the marginal willingness to pay for water along the demand curve for each study, following the point-expansion method [18]. Demand values were adjusted for some studies [6,14,15,2527] to include collective uses, based on the assumption that collective uses represent $25 \%$ of total municipal uses, the remainder corresponding to residential uses. For one of the studies [29] the number of persons per household was assumed to be 2.57 , which was the average 1990 household size in France at the time of the study (data from the French National Institute of Statistics and Economic Studies).

Some studies [6,25-27], displayed very low prices (0.49$0.86 \mathrm{USS}_{2005} / \mathrm{m}^{3}$ ), associated with very low demands (104-157 l/c/ d). One study [15] on the contrary displayed a very high demand $(369 \mathrm{l} / \mathrm{c} / \mathrm{d})$ for a higher price $\left(1.64 \mathrm{US}_{2005} / \mathrm{m}^{3}\right)$. Some studies performed the econometric estimation with a linear structural form [15,25-27], others with a log-log structural form (i.e. constant price-elasticity) $[6,14,29,33]$. The linear studies led to low slopes, with a very low WTP for water for the first litre consumed (1.59-4.98 US $\left.\$ / \mathrm{m}^{3}\right)$, and WTP in the $\left[0.57 \mathrm{US} \$ / \mathrm{m}^{3} ; 4.09 \mathrm{US} \$ / \mathrm{m}^{3}\right.$ ] range for the 100th $\mathrm{l} / \mathrm{c} / \mathrm{d}[15,25-27]$.

For low demand levels, the linear structural forms are likely to underestimate water values since estimates are much lower than prices actually paid for (e.g. bottled water, which can reach $300 \mathrm{US} \$ / \mathrm{m}^{3}$ or higher). Moreover, such low values do not agree with the notion that water is essential [5]. Values given by log-log structural forms are higher, but the econometric estimations were performed in conditions where observed demands were higher than $100 \mathrm{l} / \mathrm{c} / \mathrm{d}$. For low demand levels, i.e. the 1 st and 50th $\mathrm{l} / \mathrm{c} / \mathrm{d}$, which are far from the observations range of the estimations, we chose not to rely on econometric estimates of WTP for water and made simple assumptions (Table 3 ). For the 100th $1 / \mathrm{c} / \mathrm{d}$, values given by the linear form are much lower than values obtained with $\log -\log$ structural form. Even though there is no strong evidence 


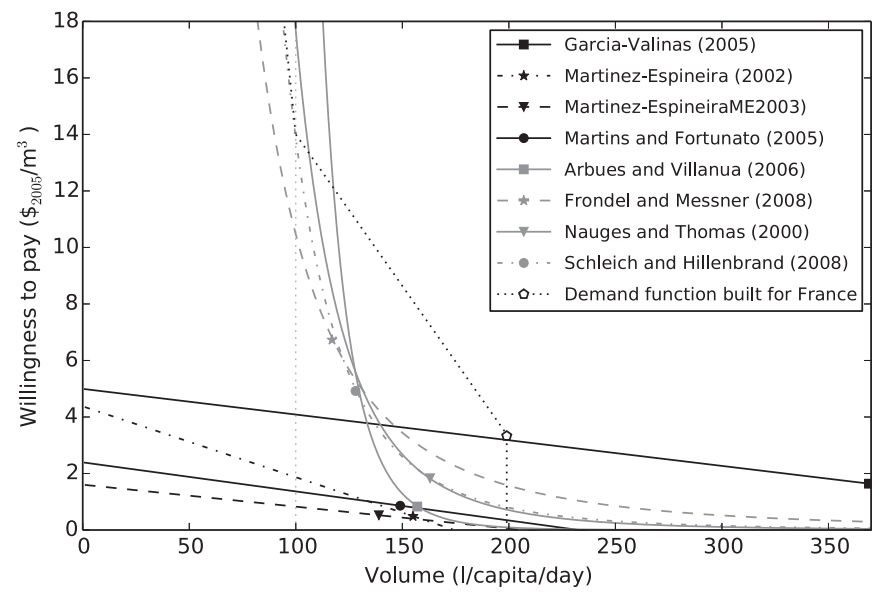

Fig. 3. Marginal willingness to pay along the demand curve, calculated from the results of various econometric studies. In grey: econometric estimations using a $\log$-log structural form, in black: linear structural form. Markers indicate the average observed levels of demand and price for each study. The dotted curve represents the demand function built for France, the pentagonal marker indicates the point of maximum potential demand calibrated for France and current water price in France.

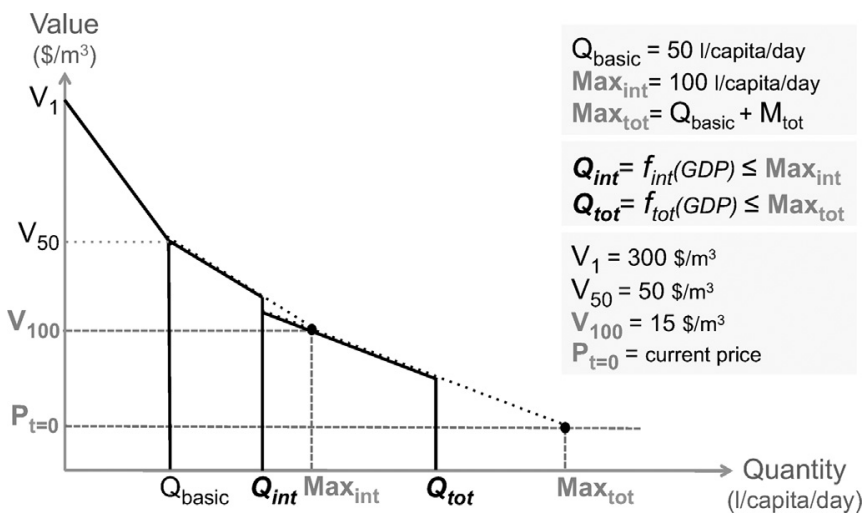

Fig. 4. Structure of the final three-parts inverse demand function and its points of reference (volumes $Q$ and values $V$ ). $Q_{\text {basic }}$ is set to $50 \mathrm{l} /$ capita/day, whereas $Q_{\text {int }}$ and $Q_{t o t}$ depend on the level of GDP per capita on the considered year. $Q_{i n t}$ and $Q_{\text {tot }}$ grow with GDP per capita with a saturation, their maximum values are respectively Max $_{\text {int }}$ and Max tot. Max $_{\text {int }}$ is set to $100 \mathrm{l} /$ capita/day, whereas Max tot $_{\text {is }}$ is calibrated at country scale.

Table 2

Marginal willingness to pay (WTP) for the 100th litre per capita per day (1/c/d), calculated from the results of four econometric studies.

\begin{tabular}{|c|c|c|c|c|c|}
\hline Reference & Location & $\begin{array}{l}\text { Observed demand }(1 / c / \\
\text { d) }\end{array}$ & Observed price $\left(U S \$_{2005} / \mathrm{m}^{3}\right)$ & $\begin{array}{l}\text { Estimated price- } \\
\text { elasticity }\end{array}$ & Marginal WTP for 100 th $\mathrm{l} / \mathrm{c} / \mathrm{d}\left(\mathrm{US} \$_{2005} / \mathrm{m}^{3}\right)$ \\
\hline Nauges and Thomas [29] & France & 163 & 1.83 & -0.215 & 17.64 \\
\hline Arbués and Villanúa [6] & Spain & 157 & 0.83 & -0.108 & 54.25 \\
\hline Frondel and Messner [14] & Germany & 117 & 6.73 & -0.365 & 10.46 \\
\hline $\begin{array}{l}\text { Schleich and Hillenbrand } \\
\text { [33] }\end{array}$ & Germany & 128 & 4.92 & -0.242 & 13.85 \\
\hline
\end{tabular}

that the values given by the linear form are incorrect, we assumed that values were too low at this demand level. Therefore, we chose to rely only on the marginal WTP for water calculated from studies using a $\log$-log structural form. Three studies remained, after which we chose not to use the results derived from Arbués and Villanúa [6], for which a high observed demand combined with a low price-elasticity implies a steeper slope and much higher values than the other studies (Fig. 3 and Table 2). Demand consists of total domestic demand (i.e. residential uses and collective uses).

The marginal WTP for the 100th $1 / \mathrm{c} / \mathrm{d}$ ranges from 10.46 to $17.64 \mathrm{US} \$ / \mathrm{m}^{3}$, with a $25 \%$ variation range around the average of 14 . We assume that the WTP for the 100 th $1 / \mathrm{c} / \mathrm{d}$ is $14 \mathrm{US} \$ / \mathrm{m}^{3}$. Because the error range of this parameter is high, it is included in the sensitivity analysis performed in Section 4.

For the upper bound of the third block, we use available data on current water price. Combining observed quantity and observed price could give us a point of the demand curve. However, if equipment limits demand, there is some rationing and the point of observed demand does not correspond to the consumption level where willingness to pay equals price and consumer's marginal surplus becomes null. To estimate this level of demand, unconstrained by equipment, we use the maximum potential demand $Q_{\text {basic }}+M_{\text {tot }}$, i.e. the plateau of the structural change function $f_{\text {tot }}$. Hence we use $Q_{\text {basic }}+M_{\text {tot }}$ and $P_{t=0}$ as a reference point of the demand curve, where $P_{t=0}$ is the current water price, determined by the authors from available data (Table 5 and Section 3.2). This point constitutes the upper bound of the third category demand block (Table 3). Then, for a given year, the third block actually ends when reaching $Q_{t o t}$, i.e. the actual total demand for the level of GDP per capita of the considered year, as demand is constrained by revenue and domestic equipment (Fig. 4).

Table 3 summarises the figures used to define the WTP for water at the bounds of the blocks of our three-part inverse demand function. Once the WTP for water at the volume points of reference of the three categories of demand has been determined, a linear interpolation is used to build the demand function. The linear form is chosen for its simplicity, in the absence of data justifying another shape.

In this way, we build a domestic demand function for each country, whose parameters take into account the impact of economic development on demand. The structure of that final

Table 3

Marginal willingness to pay (WTP) at the bounds of the blocks of the three-parts demand function, with LB: lower bound, UB: upper bound.

\begin{tabular}{|c|c|c|c|}
\hline \multicolumn{2}{|l|}{ Volume } & \multirow[t]{2}{*}{ Marginal WTP $\left(U S \$_{2005} / \mathrm{m}^{3}\right)$} & \multirow[t]{2}{*}{ Justification } \\
\hline Point of reference & 1/capita/day & & \\
\hline LB block 1 & 1st & 300 & Average price of bottled water \\
\hline UB block 1: $Q_{\text {basic }}$ & 50th & 50 & Assumption \\
\hline UB block 2: $Q_{\text {basic }}+M_{\text {int }}$ & 100th & 14 & Adapted from literature (Section 2.3) \\
\hline UB block 3: $Q_{\text {basic }}+M_{\text {tot }}$ & Country specific & $P_{t=0}$ & Point of maximum potential demand if equipment was not limiting \\
\hline
\end{tabular}


demand function is pictured in Fig. 4, where $Q_{i n t}$ and $Q_{t o t}$ are being redetermined for each year following projected GDP per capita. The total economic value of the water used can be derived from this demand function, depending on the cost of water, the price of water and the level of satisfaction of the demand: it consists of consumers' surplus plus the water utility's revenue (Appendix C). Water utility's revenue can be negative if price is lower than cost.

A sensitivity analysis is later carried out to assess the impact of the different assumptions (Section 4).

\section{Application to the Mediterranean region}

The first step is to calibrate structural change curves for each country. Then, for a given year $t$ and level of GDP per capita $G D P_{t}$, potential intermediate and total demands can be determined and used to define the volumes of the blocks of the three-part demand function for year $t$ (Fig. 4). Finally, actual demand for year $t$ can be determined depending on the price of water $P_{t}$

\subsection{Calibration of structural change curves for the Mediterranean countries}

Structural change curves parameters ( $M$ and $\gamma$, cf. Section 2.2) were calibrated for countries of the Mediterranean rim based on data available at a regional scale. Historical water demands were determined using water withdrawal data at country level from the Mediterranean Information System on Environment and Development database (SIMEDD [31]) and water withdrawal to water demand ratios (i.e. water networks' efficiency) from Margat and Treyer [23]. Population data were taken from UNO, GDP data from World Bank. All GDP figures are expressed in purchasing power parity terms, in US\$2005.

Data was available to calibrate the structural change curves for six countries (France, Italy, Israel, Malta, Slovenia, and Spain). For the other countries, historical GDP per capita is low and data is concentrated in the lower part of the sigmoid, so the plateau of the curve cannot be estimated. In such case, assumptions based on available data and assumptions on country similarities ${ }^{1}$ need to be made. For Montenegro, we used the plateau calibrated on Greece. For the remaining countries, in the absence of a suitable country of reference, we set the maximum additional demand parameter $\left(M_{\text {tot }}\right)$ and pricing $\left(P_{t=0}\right)$ to the average value in countries where it could be estimated, and calibrated only the curve parameter $\left(\gamma_{t o t}\right)$. For Montenegro, we did not have sufficient data to fit the curve parameter either, so we used the curve parameter calibrated on Greece.

Results of the calibration of the $M_{\text {tot }}$ parameter and resulting maximum potential demands for each country are presented in Table 4. The plateau level is the lowest in Malta and France, and the highest in Spain and Italy. Goodness of fit between country data and the obtained calibrated function is evaluated with Willmott index of agreement in its original form [36], which is suitable for sigmoid curves. For France, the curve fits well visually (Appendix D), but in this specific case the Willmott index is not an appropriate indicator of goodness of fit because historical consumption has already reached the plateau and observations are flat (instead of being of a sigmoid form), so the sum of squares of the regression (SSR) is null.

In our methodology the projection variable is demand, leaving the possibility of making various assumptions about the evolution of network efficiency when determining the corresponding

\footnotetext{
${ }^{1}$ Maximum potential demands should reflect cultural effects, along with other
} factors influencing domestic water demand (climate, household characteristics, etc.)
Table 4

Calibrated maximum potential demand for the different countries (where $\mathrm{m}^{3} / \mathrm{c} / \mathrm{y}$ : cubic metre per capita per year; and l/c/d: litre per capita per day).

\begin{tabular}{|c|c|c|c|c|}
\hline \multirow[t]{2}{*}{ Country } & \multirow{2}{*}{$\begin{array}{l}M_{\text {tot }} \text { parameter } \\
\left(\mathrm{m}^{3} / \mathrm{c} / \mathrm{y}\right)\end{array}$} & \multicolumn{2}{|c|}{$\begin{array}{l}\text { Maximum potential } \\
\text { demand }\end{array}$} & \multirow[t]{2}{*}{$\begin{array}{l}\text { Willmott index of } \\
\text { agreement }\end{array}$} \\
\hline & & $\left(\mathrm{m}^{3} / \mathrm{c} / \mathrm{y}\right)$ & $(\mathrm{l} / \mathrm{c} / \mathrm{d})$ & \\
\hline France & 54.52 & 72.77 & 199 & 0.00 \\
\hline Israel & 71.79 & 90.04 & 247 & 0.41 \\
\hline Italy & 92.11 & 110.36 & 302 & 0.63 \\
\hline Malta & 54.49 & 72.74 & 199 & 0.65 \\
\hline Slovenia & 82.08 & 100.33 & 275 & 0.44 \\
\hline Spain & 91.26 & 109.51 & 300 & 0.83 \\
\hline Others ${ }^{a}$ & 77.58 & 95.83 & 263 & - \\
\hline
\end{tabular}

a Albania, Algeria, Bosnia, Croatia, Cyprus, Egypt, Greece, Lebanon, Libya, Morocco, Syria, Tunisia, Turkey, and Montenegro.

withdrawal. To be able to compare our calibration results with those of the WaterGAP methodology applied to European countries [13], we converted our demand figures into withdrawals under the assumption that demand to withdrawal ratios remain equal to current ratios (average current ratios, adapted from Margat and Treyer [23], cf. Table 6). For Spain and Slovenia, our results are very similar to Flörke and Alcamo [13] findings, with less than $10 \%$ of difference in maximum potential withdrawals, whereas for France and Italy we obtain substantially lower results ( -65 to $-85 \%$ ). Flörke and Alcamo [13] perform their structural change calibration using adjusted data: they offset past improvements in water use efficiency by applying a fixed annual technological change rate. The adjusted data they use are therefore higher than historical data, which can explain the differences with our results for France and Italy. For Malta, Flörke and Alcamo [13] obtained a very low plateau (about two times lower than ours), which could be because their data do not take into account desalinated water.

\subsection{Projection scenarios}

The calibrated three-part demand curves were used for the projection and valuation of domestic water demands in the Mediterranean countries, as a function of economic development and water price. Since demands are mostly higher than the upper bound of the second block (100 l/c/d), for simplification we used the average value of water per block instead of the variable marginal value in the first two blocks of the demand functions when calculating consumer's surplus. This could lead to an underestimation of consumer's surplus when demand is lower than 100 l/c/d (Morocco before year 2010, Bosnia before 2015, Tunisia before 2020, Algeria until 2050 under the reference scenario).

Projection and valuation of future domestic water demands at the 2060 horizon were performed under contrasted scenarios of economic development and population growth. For economic development scenarios, we used GDP projections of the five Shared Socioeconomic Pathways (SSPs) [32] available in the SSP Database (version 0.9.3). For population projections, we used four UNO scenarios: the medium, low and high variants, and the constant fertility variant. The medium population variant combined with the SSP2 economic scenario is used as the reference scenario.

The cost of water was assumed to evolve over time as countries develop and invest in water infrastructures. Current cost level in France was chosen as a target cost of reference, because we consider it to be representative of a mature domestic water distribution and sewerage service, with a cost-recovery ratio close to one. We assume that, as far as conventional water resources are concerned, water costs mainly consist of distribution and sewerage costs and do not differ greatly between countries (this assumption 
is relaxed in Section 3.4). Cost evolution was hence represented as follows: in every country water cost increases over time and converges towards the current cost level in France, following the evolution of GDP per capita. It is not allowed to decrease if GDP per capita drops. Water cost reaches the target cost level when GDP per capita reaches the current level of GDP per capita in France.

For Malta, the particular context of the water sector implies a very high cost of water due to intensive desalination: $62 \%$ of the water used came from desalination in 1998-1999 [23]. For Croatia, the current cost of water is also above the target cost level. Therefore, no further increase in water cost was projected for Malta and Croatia.

The cost-recovery ratio was assumed to converge towards one as GDP per capita grows, reaching one when GDP per capita reaches the current level of GDP per capita in France. The price of water changes over time, resulting from the combination of cost evolution and cost-recovery evolution.

Current water prices and costs in each country were not directly available, they had to be reconstructed using available data on water costs or prices from Margat and Treyer [23], OECD [30] and International Benchmarking Network for Water and Sanitation Utilities database (IBNET [22]), cost-recovery ratios from Margat and Treyer [23], Euro-Mediterranean Water Information System database (EMWIS [11]) and IBNET, and sewerage coverage ratios from EMWIS and IBNET. Domestic water prices and costs are estimated with two different methods: using available data on prices and costs, or reconstructing costs based on the most robust data and sewerage coverage rates. Then the maximal value given by these two methods is selected, to avoid unrealistically low values.

For the first method, in a first step data on water prices and costs are deflated. When possible, missing costs are determined using the cost/price ratio in each country. If this information is not available, the water volumes weighted average Mediterranean cost/price ratio is used (using SIMEDD data for year 2000 water volumes). The obtained values are then multiplied by a 1.3 factor to take into account additional costs (other than operational costs). The 1.3 figure originates from data on France from Margat and Treyer [23]. Robust water costs data are available for four countries (France, Greece, Italy and Spain), the minimum estimated costs are observed for Italy $\left(2.17 \mathrm{US} \$ / \mathrm{m}^{3}\right)$. This minimum cost accounts for both water services and sanitation services, each representing 50\% of this cost. We use this value as a basis to calculate minimum costs for all the other countries in the second method.

For the second method, we estimate a minimal domestic water cost depending on the sewerage coverage rate. For countries where robust water costs data are not available, we assume that water distribution services costs are $2.17 / 2 \mathrm{US} \$ / \mathrm{m}^{3}$ (i.e. half of the minimum total cost among countries with robust data). We then add sanitation costs, which vary from 0 to $2.17 / 2 \mathrm{US} \$ / \mathrm{m}^{3}$, depending on the sewerage coverage rate.

Final cost and price data used are displayed in Table 5 .

\subsection{Projection results}

Results of projected water demand per capita are presented in Fig. 5 for a selection of countries and in Table 6. Developed countries have mostly reached demand saturation: demand per capita does not increase in France, Israel and Malta, and it increases by only $2.1 \%$ to $9.7 \%$ in Spain between 2000 and 2060 under the different scenarios. In contrast, demand per capita grows sharply in developing countries, at a pace depending on socioeconomic drivers. In Egypt, domestic water demand per capita is of $45.36 \mathrm{~m}^{3} / \mathrm{c} / \mathrm{y}$ in 2000 , and it grows rapidly and reaches potential demand around 2030-2035 (Fig. 5(a)). In Morocco and Algeria, initial demand is lower (respectively 29.97 and
Table 5

Reconstructed current costs and prices of domestic water in Mediterranean countries (around year 2000)

\begin{tabular}{|c|c|c|c|}
\hline Country & Cost $\left(\mathrm{US}_{2005} / \mathrm{m}^{3}\right)$ & Price $\left(U S \$_{2005} / \mathrm{m}^{3}\right.$ ) & $\begin{array}{l}\text { Years of available } \\
\text { data }\end{array}$ \\
\hline Albania & 1.79 & 0.93 & $<2004,2011$ \\
\hline Algeria & 2.01 & 0.41 & $<2004,2010$ \\
\hline $\begin{array}{l}\text { Bosnia and } \\
\text { Herzegovina }\end{array}$ & 1.68 & 0.93 & 2007 \\
\hline Croatia & 4.33 & 2.55 & $<2004$ \\
\hline Cyprus & 2.62 & 1.33 & $1989,<2004$ \\
\hline Egypt & 1.63 & 0.16 & $\begin{array}{l}\text { 1989, } \\
<2004,2010\end{array}$ \\
\hline France & 3.33 & 3.33 & $<2004,<2010$ \\
\hline Greece & 2.22 & 1.31 & $<2004,<2010$ \\
\hline Israel & 2.15 & 0.95 & $<2004,<2010$ \\
\hline Italy & 2.17 & 1.4 & $\begin{array}{l}1994, \\
<2004,<2010\end{array}$ \\
\hline Lebanon & 2.05 & 1.2 & $1989,<2004$ \\
\hline $\begin{array}{l}\text { Libyan Arab } \\
\text { Jamahiriya }\end{array}$ & 1.84 & 0.09 & $1997,<2004$ \\
\hline Morocco & 2.05 & 1.04 & $1989,<2004$ \\
\hline Malta & 10.58 & 2.08 & $<2004$ \\
\hline Montenegro & 1.65 & 0.93 & 2012 \\
\hline Slovenia & 2.81 & 1.66 & $<2004$ \\
\hline Spain & 2.75 & 1.62 & $<2004,<2010$ \\
\hline $\begin{array}{l}\text { Syrian Arab } \\
\text { Republic }\end{array}$ & 2.83 & 0.91 & $1989,<2004$ \\
\hline Tunisia & 1.9 & 0.91 & $\begin{array}{l}1989,1996 \\
<2004,2010\end{array}$ \\
\hline Turkey & 2.1 & 1.17 & $<2004,2008$ \\
\hline
\end{tabular}

$21.70 \mathrm{~m}^{3} / \mathrm{c} / \mathrm{y}$ in 2000); whereas it grows rapidly in Morocco, reaching potential demand around 2035-2040, it grows more slowly in Algeria where GDP per capita evolves at a slower pace, and maximum potential demand is not yet reached in 2060 under the reference scenario.

An overshoot effect is perceptible for Egypt and Morocco (Fig. 5 (a)) after 2040, as the growth of demand per capita is counterbalanced by increases in water price (with an order of magnitude of $-6.3 \%$ in demand in 2060 due to price increase). This impact of price on demand is also visible for Israel and for Spain (respectively $-10.9 \%$ and $-8.9 \%$ in 2060 ). While GDP per capita and water price remain low, demand per capita increases with economic development, and surplus per capita increases with demand. Eventually, when GDP per capita and price reach a certain level, demand per capita begins to saturate and decrease, which impacts surplus negatively. In parallel, as the country develops the cost of water increases, which also impacts surplus negatively. As a result, surplus per capita begins to decrease sooner than demand per capita. The negative net effect on surplus is visible for Egypt, Israel, Morocco, Spain and Turkey (Fig. 5(b)).

Malta is a particular case. The cost of water is the highest among Mediterranean countries: 10.58 US $\$ 2005 / \mathrm{m}^{3}$ compared with an average cost of 2.77 US $\$_{2005} / \mathrm{m}^{3}$ in the other countries. Surplus is particularly low due to this high cost of water. The impact of price on demand per capita is more pronounced for Malta $(-35.7 \%$ in 2060) than for other countries, as the price of water converges towards a higher cost.

Total demand at country scale is the result of demand per capita evolution and population growth. In some countries, such as Turkey and Egypt, the combination of a strong population growth and increase in individual water demand leads to a rapid rise of total water demand: $+170 \%$ for Turkey and $+210 \%$ for Egypt between 2000 and 2030, under the reference scenario (Fig. 5(c)). In other countries, such as Algeria, demand per capita remains limited by revenue constraints and so, despite a high population increase, total demand does not grow that sharply in the first decades: $+110 \%$ between 2000 and 2030 under the reference 

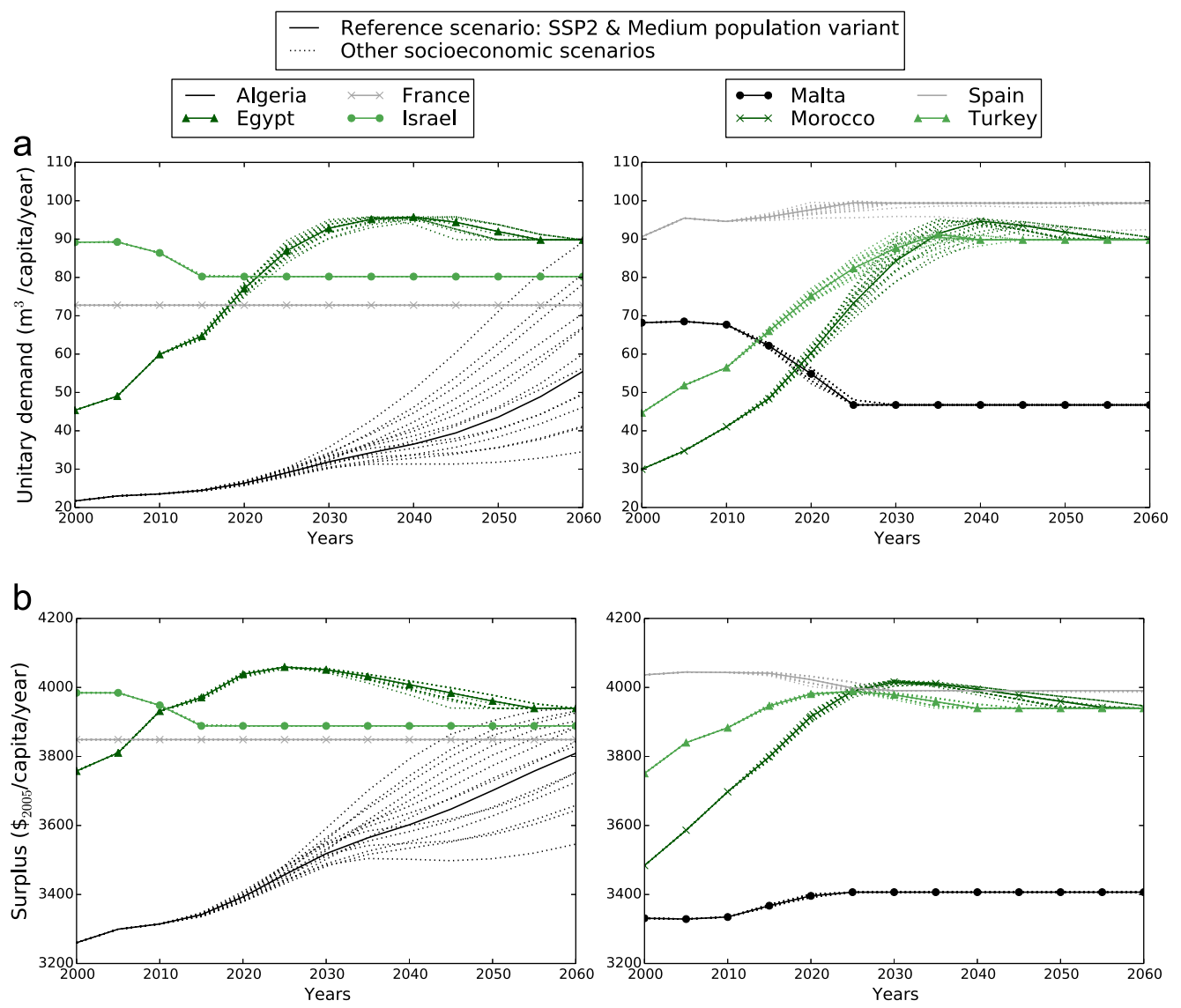

C
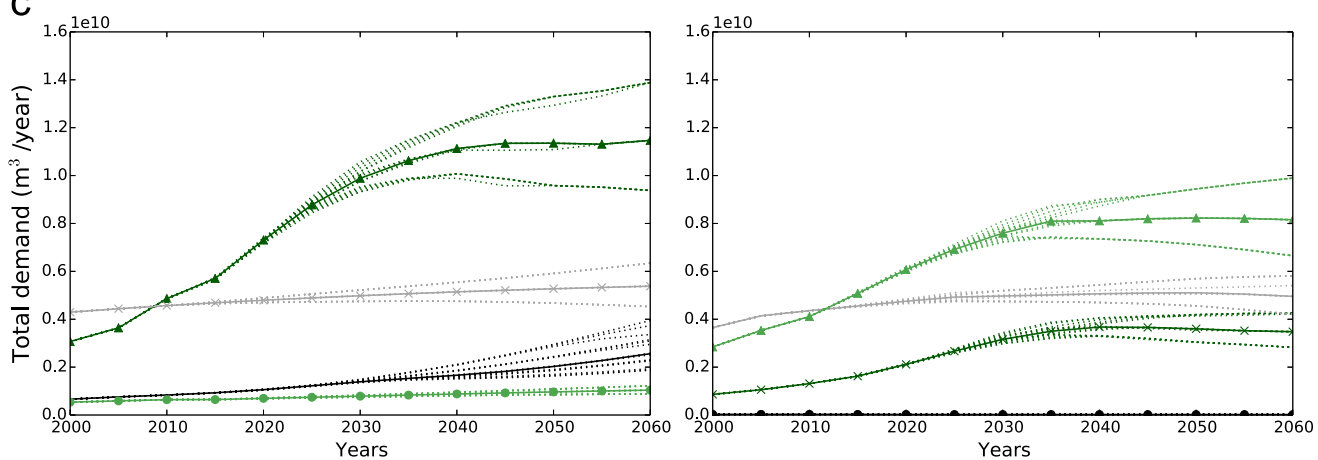

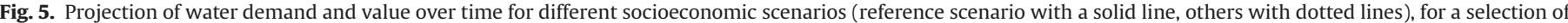
countries. (a) Demand per capita, (b) surplus per capita (consumer surplus + water utility revenue), and (c) total domestic water demand at country scale.

scenario. By 2060, total demand could almost triple under the reference scenario: $+186 \%$ in Turkey, $+273 \%$ in Egypt, and $+286 \%$ in Algeria (compared with year 2000).

We compared our results with domestic water use projections in Mediterranean countries available in the literature (Appendix E). Globally our projections fall in the range of existing figures, which can be wide for non-OECD countries.

\subsection{Simulation of a strong cost increase scenario}

Under the standard price evolution modelled in Section 3.3 (Malta not included), the effect of price increase leads to a decrease in demand of up to $10.9 \%$ in 2060 . These results were obtained under the assumption that the cost of water will converge towards the current cost in France. But if the resource is too scarce and cannot meet the growing demand, some countries might need to mobilise alternative water supply sources, that are more costly.
Taking into account demand sensitivity to price is useful for simulating stronger price increase scenarios.

As an illustration, another price evolution scenario was simulated for a selection of countries: a strong increase in the cost of water, due to the need to resort to non-conventional water resources such as desalination. In this scenario, desalination is introduced in 2020 and its share in total water production increases progressively so as to reach $25 \%$ of water demand in 2050 in $\mathrm{Al}$ geria, 50\% in Tunisia and 100\% in Libya. Such desalination rates are consistent with the fact that over $80 \%$ of current water withdrawals come from non-sustainable resources in Libya, over $30 \%$ in Algeria and over 20\% in Tunisia [23].

The cost of desalinated water is assumed to be 10.58 US $\$_{2005} / \mathrm{m}^{3}$, which is the current cost of water in Malta. ${ }^{2}$

\footnotetext{
${ }^{2}$ Costs could however become more important in the future, evolving with the cost of energy.
} 
Table 6

Projected domestic demands in Mediterranean countries for years 2010, 2025 and 2050, for the reference socioeconomic scenario.

\begin{tabular}{|c|c|c|c|c|c|c|c|}
\hline \multirow[t]{2}{*}{ Country } & \multicolumn{3}{|c|}{ Total demand $\left(\mathrm{km}^{3} / \mathrm{y}\right)$} & \multicolumn{3}{|c|}{ Demand per capita $\left(\mathrm{m}^{3} / \mathrm{c} / \mathrm{y}\right)$} & \multirow[t]{2}{*}{ Demand to withdrawal ratios (\%) } \\
\hline & 2010 & 2025 & 2050 & 2010 & 2025 & 2050 & \\
\hline Albania & 0.30 & 0.32 & 0.28 & 93.49 & 95.72 & 93.21 & 45 \\
\hline Algeria & 0.83 & 1.22 & 2.03 & 23.52 & 29.04 & 43.57 & 50 \\
\hline Bosnia and Herzegovina & 0.13 & 0.21 & 0.27 & 35.63 & 59.01 & 89.79 & 40 \\
\hline Croatia & 0.31 & 0.35 & 0.33 & 69.97 & 83.3 & 84.73 & 67.5 \\
\hline Cyprus & 0.07 & 0.08 & 0.12 & 61.54 & 64.57 & 86.39 & 77 \\
\hline Egypt & 4.86 & 8.78 & 11.35 & 59.93 & 86.96 & 91.96 & 52.5 \\
\hline France & 4.57 & 4.89 & 5.27 & 72.77 & 72.77 & 72.77 & 70 \\
\hline Greece & 0.81 & 0.91 & 1.05 & 71.6 & 78.45 & 89.79 & 66.5 \\
\hline Israel & 0.64 & 0.74 & 0.96 & 86.39 & 80.22 & 80.22 & 81.5 \\
\hline Italy & 6.21 & 6.05 & 5.86 & 102.64 & 98.99 & 98.99 & 73 \\
\hline Lebanon & 0.34 & 0.44 & 0.42 & 80.68 & 94.44 & 89.79 & 65 \\
\hline Libya & 0.55 & 0.7 & 0.79 & 87.06 & 93.94 & 89.79 & 75 \\
\hline Malta & 0.03 & 0.02 & 0.02 & 67.69 & 46.74 & 46.74 & 65 \\
\hline Montenegro & 0.02 & 0.03 & 0.05 & 32.74 & 44.38 & 74.59 & 63 \\
\hline Morocco & 1.31 & 2.67 & 3.6 & 41.07 & 73.28 & 91.81 & 78.5 \\
\hline Slovenia & 0.17 & 0.19 & 0.18 & 85.44 & 91.64 & 91.64 & 67.5 \\
\hline Spain & 4.36 & 4.92 & 5.1 & 94.61 & 99.47 & 99.38 & 70 \\
\hline Syria & 1.25 & 2.33 & 3.05 & 61.18 & 89.56 & 92.24 & 72.5 \\
\hline Tunisia & 0.33 & 0.61 & 1.14 & 31.58 & 51.29 & 89.79 & 69 \\
\hline Turkey & 4.11 & 6.92 & 8.23 & 56.5 & 82.37 & 89.79 & 50 \\
\hline
\end{tabular}

a Adapted from Margat and Treyer [23].
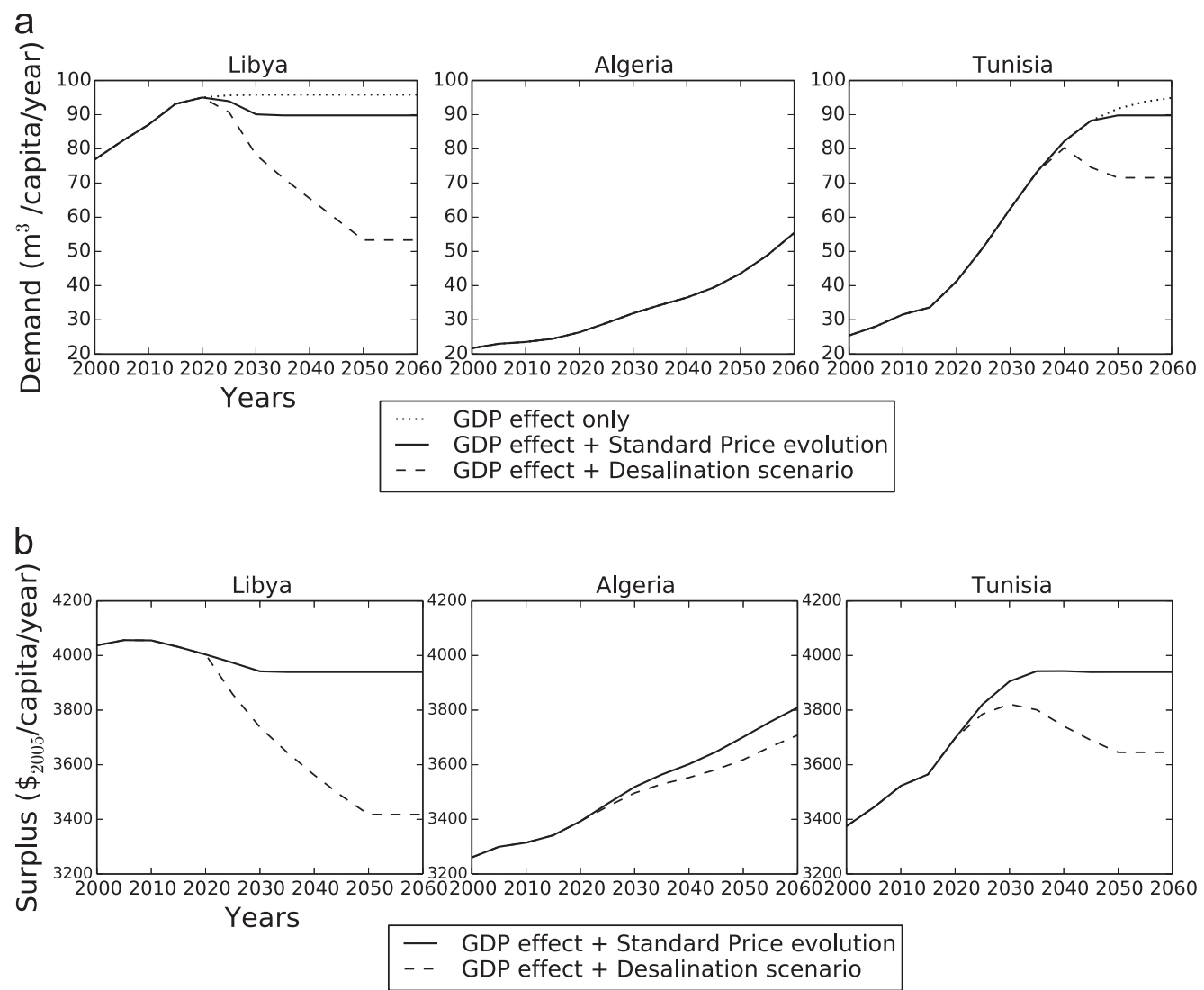

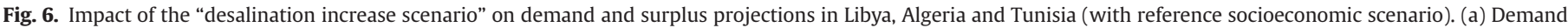
per capita and (b) surplus per capita. 
Similar to the standard price evolution scenario, the cost-recovery ratio is assumed to increase over time, converging towards one.

Impacts of this desalination scenario on demand evolution and surpluses are presented in Fig. 6, projections are performed under the reference socioeconomic scenario (SSP2 and medium variant for population).

In Algeria, the simulated price evolution scenarios do not impact demand. Indeed, in Algeria, the evolution of demand per capita is constrained by the low level of economic development, and does not reach $36.5 \mathrm{~m}^{3} / \mathrm{c} / \mathrm{y}$ until the end of the considered time horizon. Therefore, the willingness to pay for the last unit consumed is still high. In addition, cost recovery ratio stays low, so the increase in price is limited. Thus, in Algeria the revenue-effect remains stronger, even with the desalination scenario (Fig. 6). Cost still has an impact on total economic surplus since the increase in water cost lowers water utility's revenue.

For Libya and Tunisia, where the growth of GDP per capita boosts demand per capita in the next decades, the price effect decreases demands by $6.3 \%$ and $5.4 \%$ respectively in 2060 under the standard price evolution scenario. The price effect becomes more important under the implemented desalination scenario, with decreases in demands of respectively $44.36 \%$ and $24.61 \%$ for Libya and Tunisia in 2060. This illustrates how a change in water price could affect demand.

\section{Sensitivity analysis}

In the developed methodology, a number of elements could not be determined with available data and had to be considered as exogenous. A sensitivity analysis was performed to explore the impacts of the assumptions made about the value of those parameters: volume of first block $\left(Q_{\text {basic }}\right)$, parameter for maximum volume of second bock $\left(M_{i n t}\right)$, parameter for maximum potential demand $\left(M_{t o t}\right)$ for concerned countries, marginal value of the 100th $1 / \mathrm{c} / \mathrm{d}\left(V_{i n t}\right)$ and current price of water $\left(P_{t=0}\right)$. In the analysis the parameters range of variation is $[-50 \%,+100 \%]$ for parameters $M_{\text {tot }}, V_{\text {int }}$ and $P_{t=0}$. Parameter $Q_{\text {basic }}$ varies from $-60 \%$ to +40\%: the lower bound corresponds to $20 \mathrm{l} / \mathrm{c} / \mathrm{d}$ (Table 1 ), the upper bound variation is constrained so that $Q_{\text {basic }}$ remains lower than the upper bound of the second block. Then the upper bound of the second block varies from $-20 \%$ to $+40 \%$, which corresponds to a variation range of $[-78 \%,+136 \%]$ of the $M_{\text {int }}$ parameter.

The sensitivity of projected demands to $M_{\text {tot }}$ parameter was checked for the countries where it could not be calibrated (countries with a low current level of GDP per capita, cf. Section 3.1 and Table 4) and was unsurprisingly found to be determinant when countries approach the demand plateau (Fig. 7). Projection scenarios would hence need to be readjusted when there is more precise data or scenarios on maximum potential demand in those developing countries of the Mediterranean. The model is more robust to the other parameters settings (Fig. 7). Under the reference socioeconomic scenario, the impact of the combined variations of $Q_{\text {basic }}, M_{\text {int }}, V_{\text {int }}$ and $P_{t=0}$ parameters on demand per capita in 2060 in the different countries is an average $[-38 \%,+23 \%]$ range of variation around the mean.

Regarding the projection of the economic value of water, the most important parameter is $Q_{\text {basic }}$ (Fig. 7). This result is not surprising since water is very highly valued in the first block of the demand function. Under the reference socioeconomic scenario, the combined variations of $Q_{b a s i c}, M_{i n t}, V_{i n t}$ and $P_{t=0}$ parameters lead to an average variation around the mean of $[-16 \%,+31 \%]$ in surplus per capita in 2060 in the different countries.

\section{Discussion and conclusion}

The presented methodology can project the combined impact of economic development and water price on future domestic water demands, in terms of both quantity and economic benefits.

The method was applied to a region with heterogenous levels of development. The decision to use the same generic methodology for both developed and developing countries is debatable. We found that it was not possible to fully calibrate the structural change curves used to build the final demand function, for a number of countries past data alone did not enable to determine the level of demand saturation. Still, the methodology enables us to capture some socioeconomic determinants of the rate of change, via the calibration of the slope parameter of the structural change curves. In addition, when some countries are expected to catch up with some others, it makes sense to use a method suitable for different stages of the same evolution process. Indeed,
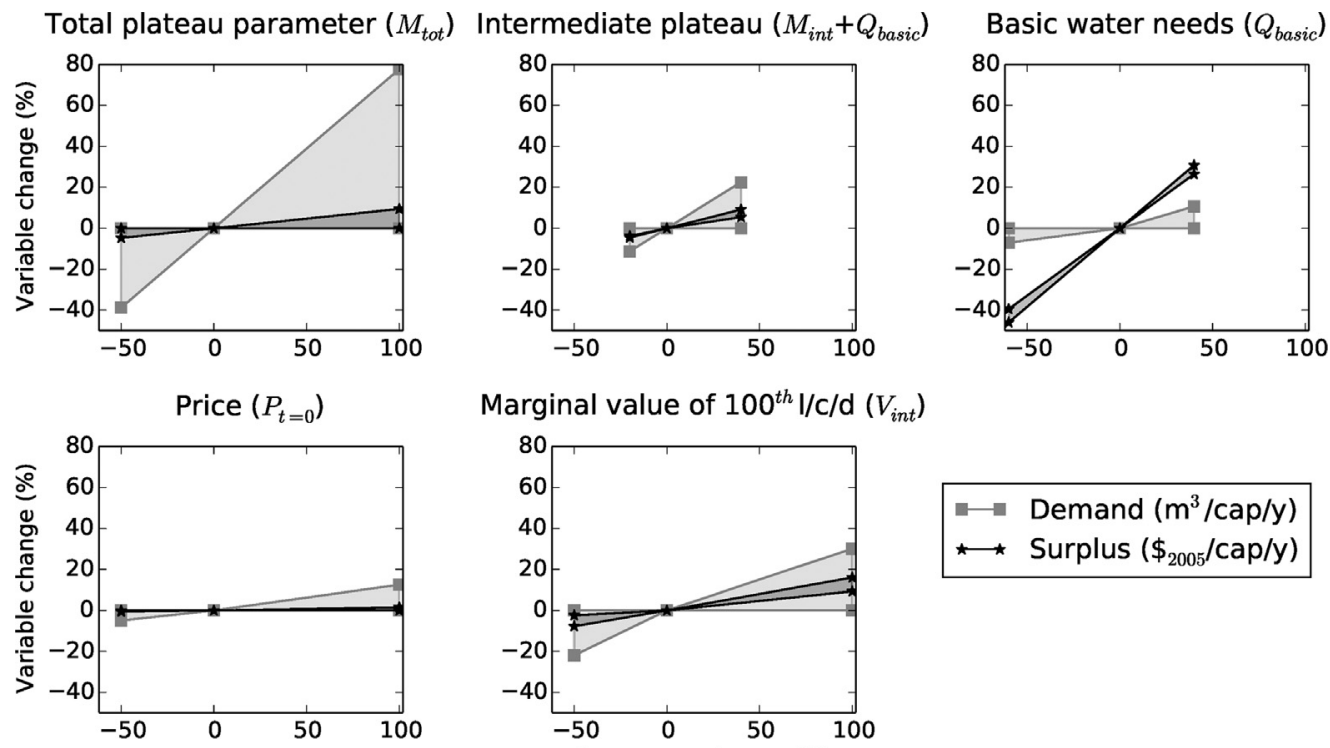

Marginal value of $100^{\text {th }} \mathrm{l} / \mathrm{c} / \mathrm{d}\left(V_{\text {int }}\right)$
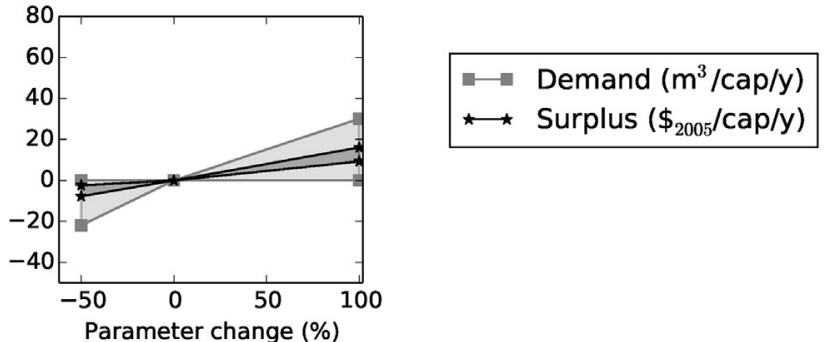

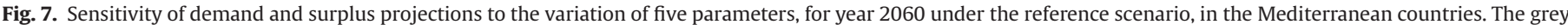
area represents the range of variation between countries. 


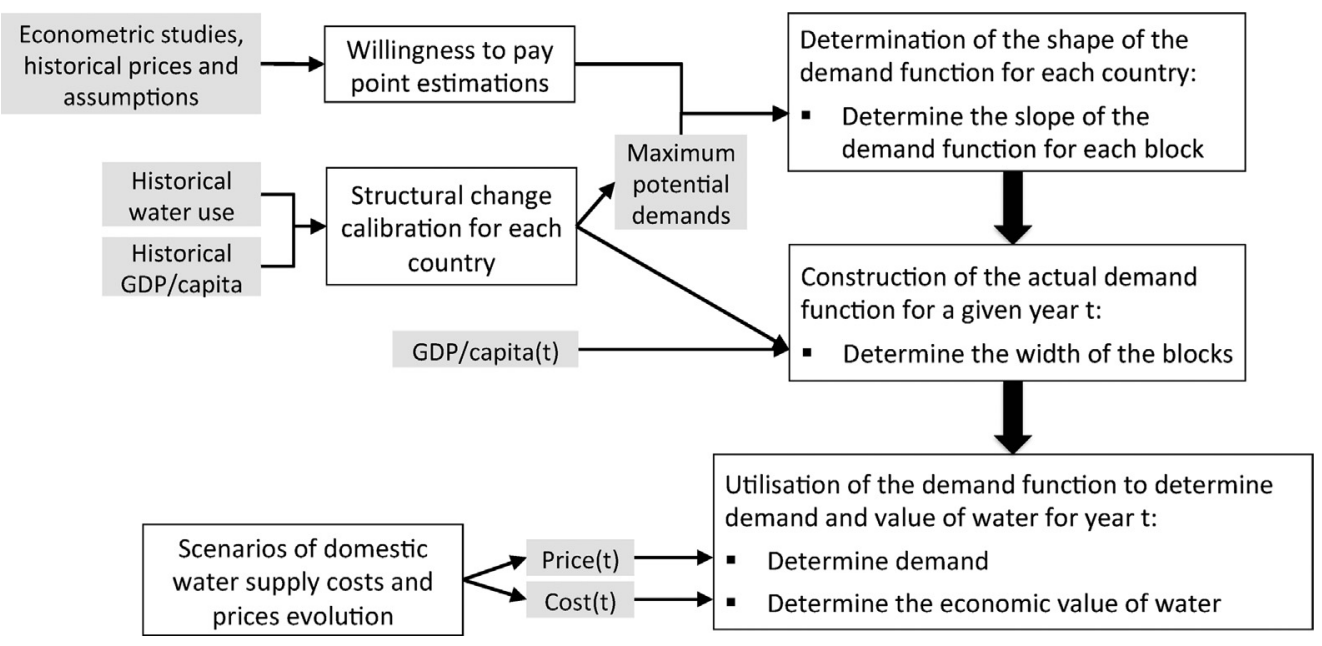

Fig. A1. Main steps of the generic methodology developed to project and value domestic water demands.

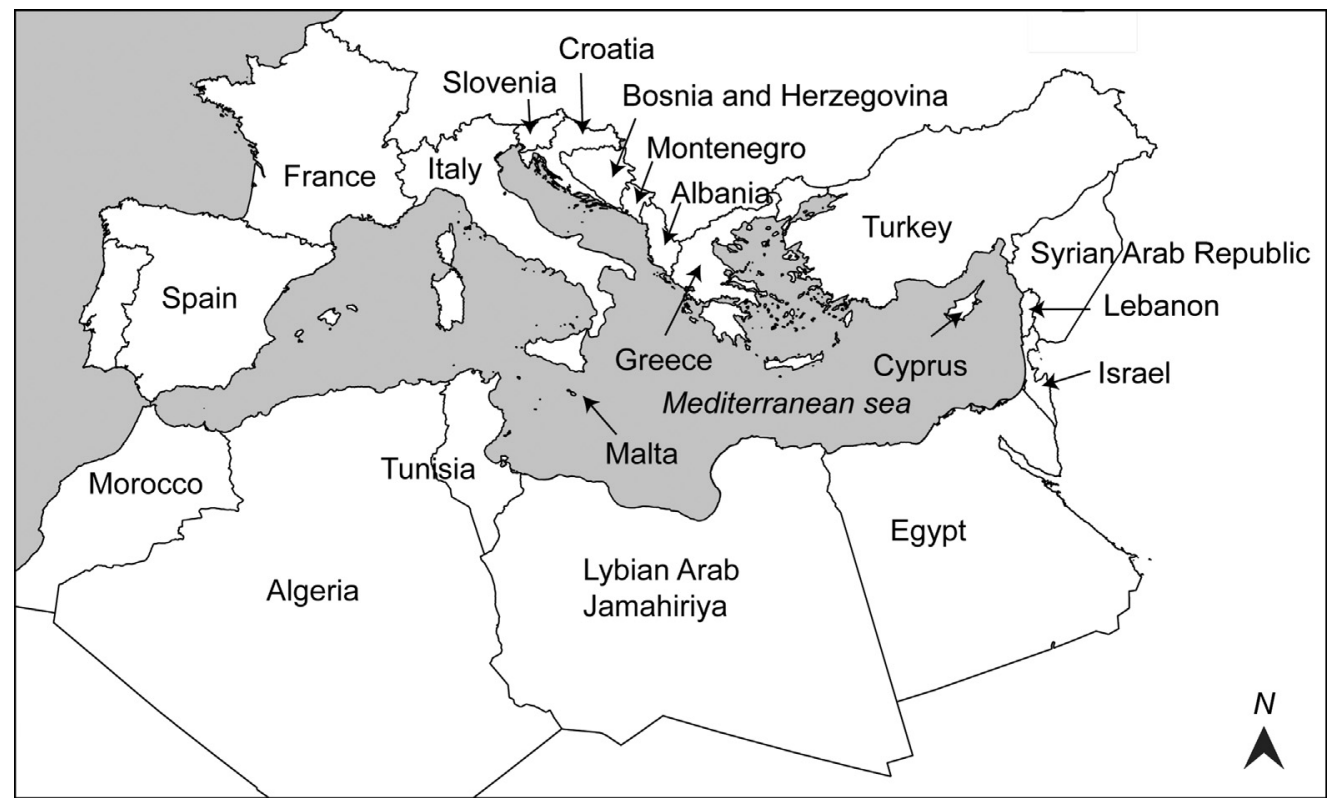

Fig. B1. Countries of the Mediterranean basin.

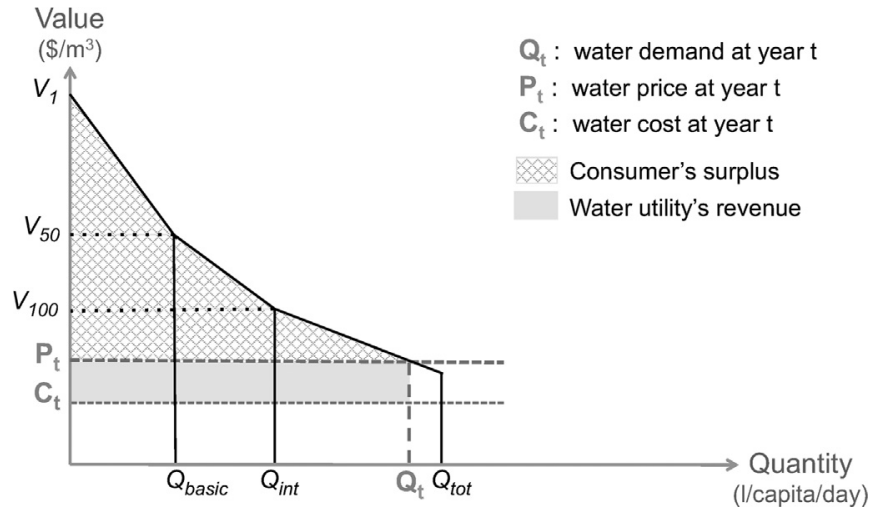

Fig. C1. Total economic value of water: consumer's surplus and water utility's revenue.

some countries are still at the beginning of the process, some midway and some already at the end. It is very likely that developing countries will undergo structural change, shifting from demand

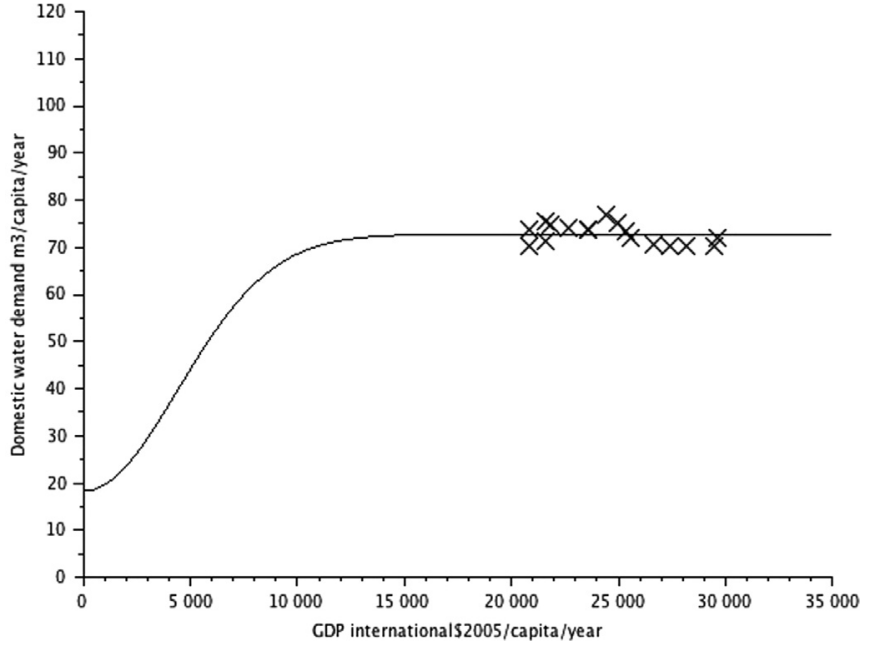

Fig. D1. Calibration of the structural change curve for France, based on historical domestic demand and GDP per capita. 

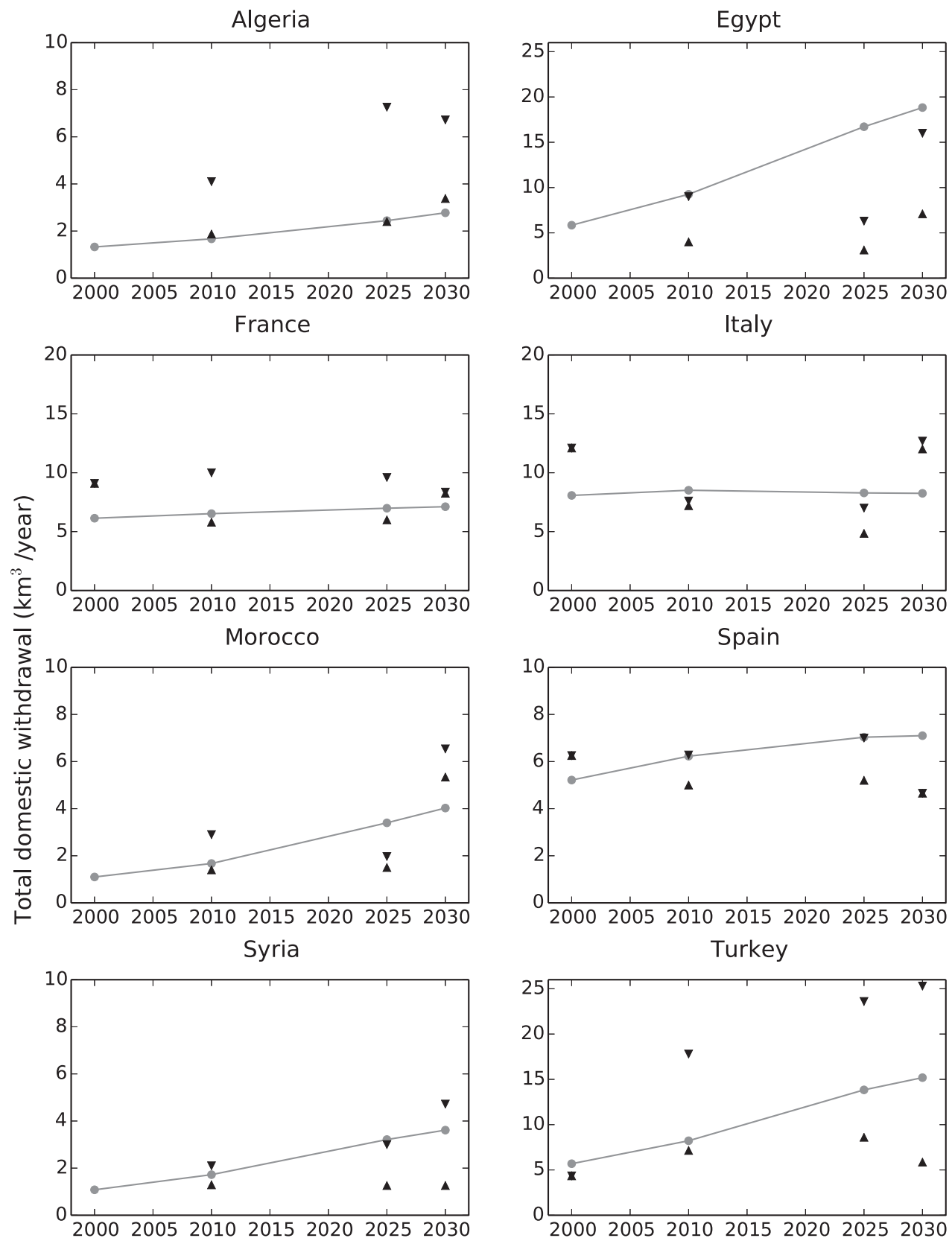

$\begin{array}{cl}\longrightarrow & \text { Projections (reference scenario) } \\ \text { \} \quad \text { Minimum from literature } } \\{ }\end{array}$

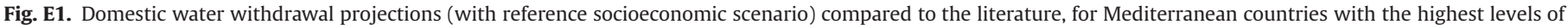
domestic withdrawal.

being constrained by equipment and revenue to demand being constrained by water costs, so we try to represent how this may happen even if there is currently no data to fully calibrate the process.

A number of parameters could not be determined with the available data, and were considered to be exogenous (Section 3.1). For instance, the levels of demand saturation for most countries converge towards the exogenously fixed average calibrated plateau. On the one hand this points out a limitation of the methodology which, although generic, is not able to capture all features with globally available data. On the other hand such exogenous parameters arise from the incomplete knowledge of future conditions, and can enable the simulation of different exploratory scenarios. It is possible to readjust scenarios when new data or more precise scenarios about the exogenous elements of the methodology become available.

Other parameters were determined using ad hoc assumptions (e.g. willingness to pay for the 100th and the 50th $1 / \mathrm{c} / \mathrm{d}$ ). Better evidence could improve parameter determination in the future. In the Mediterranean, the sensitivity analysis showed that a variation of $[-50 \%,+100 \%]$ in WTP for the 100 th $1 / \mathrm{c} / \mathrm{d}$ led to a variation of $[-22 \%,+30 \%]$ in demand per capita (Section 4). Our demand projection approach does not explicitly account for technological change, nor does it consider evolutions in cultural effects. The level of demand saturation could indeed evolve over time with technological change improving water efficiency, although a rebound 
Table E1

Projections of total domestic water use at country scale for four years of reference: elements from the literature $\left(\mathrm{km}^{3} / \mathrm{year}\right)$.

\begin{tabular}{|c|c|c|c|c|c|c|c|c|c|c|c|c|}
\hline \multirow{2}{*}{$\begin{array}{l}\text { Year } \\
\text { Source }\end{array}$} & \multirow{2}{*}{$\begin{array}{l}2000 \\
\mathrm{FA}^{\mathrm{a}}\end{array}$} & \multicolumn{4}{|l|}{2010} & \multicolumn{4}{|l|}{2025} & \multicolumn{3}{|l|}{2030} \\
\hline & & $\mathrm{AI}^{\mathrm{b}}$ & $\mathrm{NP}^{\mathrm{c}}$ & $\mathrm{PB}^{\mathrm{d}}$ & $\mathrm{MV}^{\mathrm{e}}$ & $\mathrm{Al}^{\mathrm{b}}$ & $\mathrm{NP}^{\mathrm{c}}$ & $\mathrm{PB}^{\mathrm{d}}$ & $\mathrm{MV}^{\mathrm{e}}$ & $\mathrm{FA}^{\mathrm{a}}$ & $\mathrm{AI}^{\mathrm{b}}$ & $\mathrm{NP}^{\mathrm{c}}$ \\
\hline Albania & & 0.83 & 0.83 & 0.83 & & & 0.8 & 0.80 & & & & \\
\hline Algeria & & $1.87-3.58$ & $2.0-3.26$ & 2 & 4.10 & $4.86-7.26$ & $3.1-4.9$ & 2.4 & 6.05 & & $3.38-6.72$ & \\
\hline Bosnia & & & 0.4 & & & 0.4 & & & & & & \\
\hline Croatia & & & 0.9 & & 0.78 & 0.8 & & & & & & \\
\hline Cyprus & 0.103 & & 0.09 & 0.08 & 0.10 & & & 0.1 & 0.10 & $0.094-0.104$ & & \\
\hline Egypt & & $4.0-9.0$ & 4.5 & 5 & 5.00 & $4.3-6.3$ & 3.1 & 6 & 6.00 & & $7.1-16$ & \\
\hline France & 9.097 & & 10 & 5.8 & 7.90 & & 8.03 & 6 & 9.60 & $8.256-8.356$ & & \\
\hline Greece & 1.343 & & & 0.9 & 1.50 & & 1.83 & 1 & 1.80 & $1.495-1.5$ & & \\
\hline Israel & & 0.77 & 0.86 & 0.77 & & $1.3-1.4$ & 1.15 & 1.40 & & & & \\
\hline Italy & 12.098 & & & 7.2 & 7.60 & & 4.85 & 7 & 5.20 & $12.018-12.688$ & & \\
\hline Lebanon & & $0.33-0.55$ & & 0.4 & 0.40 & $0.48-0.64$ & & 0.52 & 0.52 & & $0.63-0.98$ & 0.72 \\
\hline Libya & & 0.55 & $0.708-1.01$ & 0.71 & 1.00 & $1.49-1.93$ & $1.24-1.76$ & 1.28 & 1.76 & & $1.06-2.54$ & \\
\hline Malta & 0.022 & & & 0.04 & 0.04 & & & 0.04 & 0.04 & $0.015-0.017$ & & \\
\hline Morocco & & $1.97-2.9$ & 1.59 & 1.4 & 1.60 & $1.5-1.97$ & & 1.9 & 1.57 & & $5.34-6.54$ & \\
\hline Slovenia & 0.268 & & & 0.3 & & & 0.3 & & $0.154-0.17$ & & & \\
\hline Spain & 6.255 & & & 5 & 6.28 & & & 5.2 & 7.00 & 4.655 & & \\
\hline Syria & & $1.29-1.62$ & 2.1 & 1.4 & 2.10 & $1.26-1.94$ & & 2 & 3.00 & & $1.26-3.04$ & 4.72 \\
\hline Tunisia & & 0.57 & $0.37-0.63$ & 0.41 & 0.42 & $0.57-0.65$ & & 0.5 & 0.53 & & $1.1-1.67$ & $0.53-0.55$ \\
\hline Turkey & 4.346 & & 7.15 & 7.15 & 17.80 & & & 8.6 & 23.60 & $5.862-11.656$ & & 25.3 \\
\hline
\end{tabular}

a Flörke and Alcamo [13], range of results of 4 scenarios simulated with WaterGAP.

${ }^{\mathrm{b}}$ Arab Institutions, in Margat and Treyer [23].

c National planification documents, in Margat and Treyer [23].

d Plan Bleu [31], moderate trend scenario, in Margat and Treyer [23].

e National planning documents completed with various sources, moderate trend scenario, in Margat and Vallée [24].

Table E2

Projection of total domestic water use at country scale, comparison with elements from the literature for four years of reference ( $\mathrm{km}^{3} / \mathrm{year}$ ).

\begin{tabular}{|c|c|c|c|c|c|c|c|c|}
\hline \multirow[t]{2}{*}{ Country } & \multicolumn{4}{|c|}{ Projected withdrawals ${ }^{\mathrm{a}}$} & \multicolumn{4}{|c|}{ Range of results from the literature } \\
\hline & 2000 & 2010 & 2025 & 2030 & 2000 & 2010 & 2025 & 2030 \\
\hline Albania & 0.52 & 0.67 & 0.7 & 0.7 & & $0.8-0.83$ & 0.8 & \\
\hline Algeria & 1.33 & 1.67 & 2.44 & 2.77 & & $1.87-4.1$ & $2.4-7.26$ & $3.38-6.72$ \\
\hline Bosnia and Herzegovina & 0.25 & 0.33 & 0.53 & 0.61 & & 0.4 & 0.4 & \\
\hline Croatia & 0.36 & 0.46 & 0.52 & 0.54 & & 0.9 & $0.78-0.8$ & \\
\hline Cyprus & 0.07 & 0.09 & 0.11 & 0.12 & $0.08-0.1$ & 0.1 & $0.094-0.104$ & \\
\hline Egypt & 5.85 & 9.26 & 16.71 & 18.83 & & $4.0-9.0$ & $3.1-6.3$ & $7.1-16$ \\
\hline France & 6.14 & 6.53 & 6.99 & 7.12 & 9.097 & $5.8-10$ & $6-9.6$ & $8.256-8.356$ \\
\hline Greece & 1.02 & 1.22 & 1.37 & 1.45 & 1.343 & $0.9-1.5$ & $1-1.83$ & $1.495-1.5$ \\
\hline Israel & 0.66 & 0.79 & 0.91 & 0.97 & & $0.77-0.86$ & $1.15-1.4$ & \\
\hline Italy & 8.07 & 8.51 & 8.29 & 8.25 & 12.098 & $7.2-7.6$ & $4.85-7$ & $12.018-12.688$ \\
\hline Lebanon & 0.34 & 0.52 & 0.67 & 0.67 & & $0.33-0.55$ & $0.48-0.64$ & $0.63-0.98$ \\
\hline Libya & 0.54 & 0.74 & 0.93 & 0.93 & & $0.55-1.01$ & $1.28-1.93$ & $1.06-2.54$ \\
\hline Malta & 0.04 & 0.04 & 0.03 & 0.03 & 0.022 & 0.04 & 0.04 & $0.015-0.017$ \\
\hline Morocco & 1.1 & 1.67 & 3.4 & 4.03 & & $1.4-2.9$ & $1.5-1.97$ & $5.34-6.54$ \\
\hline Slovenia & 0.21 & 0.26 & 0.28 & 0.28 & 0.268 & 0.3 & 0.3 & $0.154-0.17$ \\
\hline Spain & 5.21 & 6.23 & 7.03 & 7.1 & 6.255 & $5-6.28$ & $5.2-7$ & 4.655 \\
\hline Syria & 1.08 & 1.72 & 3.21 & 3.61 & & $1.29-2.1$ & $1.26-3$ & $1.26-3.04$ \\
\hline Tunisia & 0.35 & 0.48 & 0.89 & 1.11 & & $0.37-0.63$ & $0.5-0.65$ & $1.1-1.67$ \\
\hline Turkey & 5.69 & 8.22 & 13.84 & 15.19 & 4.346 & $7.15-17.8$ & $8.6-23.6$ & $5.862-11.656$ \\
\hline
\end{tabular}

a Our demand projection results were converted into withdrawals using demand to withdrawal ratios adapted from Margat and Treyer [23].

effect could lead to an increase in per capita demand. Water price increase could be an incentive to invest in less water-intensive devices. However, we did not specifically model technical change. First, it is difficult to distinguish the effect of technological progress from the effect of revenue and price evolution. Indeed, the adoption of more technologically efficient water appliances by a household should somehow be conditioned by the level of GDP per capita, which constrains the purchase of a new appliance (the technology must be available but also affordable). Second, though technological change would be expected to have an effect it is not visible in the data we used for the application of the methodology to the Mediterranean: for now the available data do not show a decrease in per capita domestic water intensity even in countries which have already reached demand saturation. Thus, unlike
Alcamo et al. [1], we do not correct data for technological change before estimating the parameters of the sigmoid structural change curve. In fact, the sigmoid curve we estimate accounts for both structural change effects and embedded technological change effects (which may have slowed down demand increase), as a function of GDP per capita. In particular, once a country has reached the demand plateau there is no further technological change, unlike in the WaterGAP modelling [1].

Technological change and cultural changes could however become more important in the future. Though data from developed countries can give us an idea of the current value of the demand saturation plateau, future pathways are not easily predictable. Demand evolution parameters are estimated with historical data, and their validity to represent future evolutions is uncertain [17], 
breaks in trend could arise.

In conclusion, given the scale of the study and the scarce globally available data, especially for countries from the eastern and southern Mediterranean rims, a generic method seems appropriate. Despite identified limitations for the least-developed countries, it has the merit of offering a comprehensive estimation of future domestic water demands and values in the region. Since the methodology is generic and not too data intensive, it can be easily transposed to other large-scale regions of applications, in particular developing regions where little reliable data are available. Assumptions on costs and costs evolution, and on source of missing parameters need to be made on a per country basis, depending on available data.

The novelty of the method lies in its taking into account of the economic value of water in a large scale projection framework. It makes it possible to evaluate impacts of water scarcity in terms of welfare, measured by surplus losses. The method can simulate the impacts of different price evolution scenarios. Projection results showed that price increase can limit water demands (Section 3.4), which illustrates the potential of incentive water pricing policies. This result is interesting in view of demand-side water management, since limiting water abstractions instead of developing water supply infrastructure could reduce the burden of adaptation to climate change [21].

This work's large scale, both geographical and temporal, is suitable to study the impacts of global socioeconomic and hydroclimatic changes on the water sector and consider potential interactions between sub-basins. Some models compare water availability and water abstraction on a large scale $[17,8]$, not taking into account the value of water. Our work opens up the possibility of using water values in this type of framework, to assess water uses' economic benefits and model water allocation between competitive uses.

\section{Acknowledgements}

This work was financially supported by DGA (Direction G'en'erale del'Armement), through a Ph.D. grant. The authors would like to thank the anonymous reviewers for their constructive remarks, and in particular a reviewer for his many comments and suggestions to improve the manuscript.

\section{Appendix A. Overview of the methodology}

See Fig. A1.

\section{Appendix B. Map of the Mediterranean basin}

See Fig. B1.

\section{Appendix C. Domestic water demand function and the eco- nomic value of water}

See Fig. C1.

\section{Appendix D. Calibration of the structural change curve for France}

\section{See Fig. D1.}

\section{Appendix E. Comparison with previous domestic water use}

\section{projection attempts in the Mediterranean region}

We compare our results with domestic water use projections in Mediterranean countries available in the literature: figures from various sources displayed in Margat and Vallée [24] and Margat and Treyer [23] and results of the WaterGAP model applied to European countries from Flörke and Alcamo [13].

The elements of comparison, available for four years of reference, are displayed in Fig. E1, Tables E1 and E2, along with our results for the reference socio-economic scenario. Globally our projections fall in the range of existing figures, which can be wide for some countries (Algeria, Egypt, Libya, Syria, and Turkey).

In some countries demand increase is more rapid with our methodology and projected demand is high in 2025 (Lebanon, Tunisia, Syria, Morocco, and Egypt) compared with the literature range. The difference tends to reduce afterwards, with lower projections for 2030 with our methodology (Algeria, France, Morocco, Tunisia, and Italy). This pattern - higher projections for 2025 , but closer to or below literature range in 2030 - is probably due to the sigmoid structural form we used for structural change modelling (steep curve followed by a saturation), whereas most Mediterranean projections from national planning are based upon trend prolongation [23]. In addition, our modelling of price impact tends to reduce demand per capita once GDP per capita reaches high levels.

Still, for some countries our projections for year 2030 fall above literature range (Egypt, Malta and Spain, cf. Fig. E1 and Table E2). However, for Malta and Spain there is only one study providing projections to 2030. Prolongating the trends of the other studies would lead to higher demands than projected by our methodology. For Egypt, the literature range is very wide ( $-39 \%$ to $+39 \%)$ which denotes a high level of uncertainty.

\section{References}

[1] J. Alcamo, P. Döll, T. Henrichs, F. Kaspar, B. Lehner, T. Rösch, S. Siebert, Devel opment and testing of the WaterGAP 2 global model of water use and availability, Hydrol. Sci. J. 48 (3) (2003) 317-337.

[2] J. Alcamo, P. Döll, T. Henrichs, F. Kaspar, B. Lehner, T. Rösch, S. Siebert, Global estimates of water withdrawals and availability under current and future "business-as-usual" conditions, Hydrol. Sci. J. 48 (3) (2003) 339-348.

[3] J. Alcamo, M. Flörke, M. Märker, Future long-term changes in global water resources driven by socio-economic and climatic changes, Hydrol. Sci. J. 52 (2) (2007) 247-275.

[4] J.A. Allan, 'Virtual water': A Long Term Solution for Water Short Middle Eastern Economies?. School of Oriental and African Studies, University of London, 1997.

[5] F. Arbués, M.A. García-Valiñas, R. Martínez-Espiñeira, Estimation of residential water demand: a state-of-the-art review, J. Socio-Econ. 32 (1) (2003) 81-102.

[6] F. Arbués, I. Villanúa, Potential for pricing policies in water resource management: estimation of urban residential water demand in Zaragoza, Spain, Urban Stud. 43 (13) (2006).

[7] V. Barros, C. Field, D. Dokken, M. Mastrandrea, K. Mach, T. Bilir, M. Chaterjee, K. Ebi, Y. Estrada, R. Genova, B. Girma, E. Kissel, A. Levy, S. MacCracken, P. Mastrandrea, L. White, Climate Change 2014: Impacts, Adaptation, and Vulnerability, Part B: Regional Aspects. Contribution of Working Group II to the Fifth Assessment Report of the Intergovernmental Panel on Climate Change, USA Cambridge University Press Edition, IPCC Cambridge, United Kingdom, New York, 2014.

[8] H. Biemans, I. Haddeland, P. Kabat, F. Ludwig, R.W.A. Hutjes, Impact of reservoirs on river discharge and irrigation water supply during the 20th century, Water Resour. Res. 47 (3) (2011) 2421-2442.

[9] H. de Haas, Mediterranean migration futures: patterns, drivers and scenarios, Glob. Environ. Change 21 (2011) S59-S69.

[10] P. Döll, S. Siebert, Global modeling of irrigation water requirements, Water Resour. Res. 38 (4) (2002) 8-1-8-10.

[11] Euro-Mediterranean Water Information System, Countries water profiles. URL: 〈www.semide.net/thematicdirs/leaflet/countries-water-profiles〉, 2013.

[12] M. Falkenmark, G. Lindh, Water and economic development, in: P.H. Gleick (Ed.), Water in Crisis. A Guide to the World's Freshwater Resources, UK Oxford University Press, Oxford, 1993, pp. 80-91.

[13] M. Flörke, J. Alcamo, European outlook on water use. Final report, Center for Environmental Systems Research, University of Kassel, Germany, 2004.

[14] M. Frondel, F. Messner, Price perception and residential water demand: evidence from a German household panel, in: The 16th Annual Conference of the 
European Association of Environmental and Resource Economists Gothenburg, Sweden, 2008

[15] M.A. García-valiñas, Efficiency and equity in natural resources pricing: a proposal for urban water distribution service, Environ. Resour. Econ. 32 (2) (2005) 183-204.

[16] P.H. Gleick, Basic water requirements for human activities: meeting basic needs, Water Int. 21 (2) (1996) 83-92.

[17] N. Hanasaki, S. Fujimori, T. Yamamoto, S. Yoshikawa, Y. Masaki, Y. Hijioka, M. Kainuma, Y. Kanamori, T. Masui, K. Takahashi, S. Kanae, A global water scarcity assessment under shared socio-economic pathways-Part 1: Water use, Hydrol. Earth Syst. Sci. 17 (7) (2013) 2375-2391.

[18] J.J. Harou, M. Pulido-Velazquez, D.E. Rosenberg, J. Medellín-Azuara, J.R. Lund, R.E. Howitt, Hydro-economic models: concepts, design, applications, and future prospects, J. Hydrol. 375 (3-4) (2009) 627-643.

[19] A. Hayashi, K. Akimoto, T. Tomoda, M. Kii, Global evaluation of the effects of agriculture and water management adaptations on the water-stressed population, Mitig. Adapt. Strateg. Glob. Change 18 (5) (2013) 591-618.

[20] G. Howard, J. Bartram, Domestic Water Quantity, Service Level, and Health, World Health Organization, Geneva, Switzerland, 2003.

[21] G. Hughes, P. Chinowsky, K. Strzepek, The costs of adaptation to climate change for water infrastructure in OECD countries, Util. Policy 18 (3) (2010) 142-153.

[22] International Benchmarking Network for Water and Sanitation Utilities. Database. URL: 〈www.ib-net.org/production/〉, 2013.

[23] J. Margat, S. Treyer, L'eau des méditerranéens: situation et perspectives. Technical Report 158, UNEP-MAP (Mediterranean Action Plan), 2004.

[24] J. Margat, D. Vallée, Vision méditerranéenne sur l'eau, la population et l'environnement au XXIeme siecle/Mediterranean Vision for Water, Population and the Environment in the 21st Century, Technical Report, Plan Bleu, MEDTAC GWP, 1999.

[25] R. Martins, A. Fortunato, Residential Water Demand Under Block Rates: A Portuguese Case Study, Estudos do GEMF 9, Grupo de Estudos Monetários e Financeiros, Coimbra, Portugal, 2005.

[26] R. Martínez-Espiñeira, Residential water demand in the northwest of Spain,
Environ. Resour. Econ. 21 (2) (2002) 161-187.

[27] R. Martínez-Espiñeira, Estimating water demand under increasing-block tariffs using aggregate data and proportions of users per block, Environ. Resour Econ. 26 (1) (2003) 5-23.

[28] J. Medellín-Azuara, J.J. Harou, M.A. Olivares, K. Madani, J.R. Lund, R.E. Howitt, S. K. Tanaka, M.W. Jenkins, T. Zhu, Adaptability and adaptations of California's water supply system to dry climate warming, Clim. Change 87 (S1) (2008) 75-90.

[29] C. Nauges, A. Thomas, Privately operated water utilities, municipal price negotiation, and estimation of residential water demand: the case of France, Land Econ. 76 (1) (2000) 68-85.

[30] OECD, Pricing Water Resources and Water and Sanitation Services. Technical Report, OECD Studies on Water, 2010

[31] Plan Bleu, Mediterranean Information System on Environment and Development. URL: 〈simedd.planbleu.org/simedd〉, 2012.

[32] J. Rozenberg, C. Guivarch, R. Lempert, S. Hallegatte, Building SSPs for climate policy analysis: a scenario elicitation methodology to map the space of possible future challenges to mitigation and adaptation, Clim. Change 122 (3) (2014) 509-522.

[33] J. Schleich, T. Hillenbrand, Determinants of residential water demand in Germany, Ecol. Econ. 68 (6) (2009) 1756-1769.

[34] Y. Shen, T. Oki, N. Utsumi, S. Kanae, N. Hanasaki, Projection of future world water resources under SRES scenarios: water withdrawal, Hydrol. Sci. J. 53 (1) (2008) 11-33.

[35] P.J. Ward, K.M. Strzepek, W.P. Pauw, L.M. Brander, G.A. Hughes, J.C.J.H. Aerts, Partial costs of global climate change adaptation for the supply of raw industrial and municipal water: a methodology and application, Environ. Res. Lett. 5 (4) (2010) 044011.

[36] C.J. Willmott, On the validation of models, Phys. Geography 2 (1981) 184-194.

[37] R.A. Young, Determining the Economic Value of Water: Concepts and Methods, Resources for the Future, 2005. 